\title{
Leptin and reproduction
}

\author{
Nigel Hoggard ${ }^{*}$, Leif Hunter ${ }^{1}$, Paul Trayhurn ${ }^{1}$, Lynda M. Williams ${ }^{2}$ and Julian G. Mercer ${ }^{2}$ \\ ${ }^{1}$ Molecular Physiology Group and ${ }^{2}$ Molecular Neuroendocrinology Unit, Rowett Research Institute, \\ Greenburn Road, Bucksburn, Aberdeen AB21 9SB, UK
}

Fertility in mammals requires adequate nutrition and a certain reserve of metabolic fuel (Van Der Spuy, 1985). Individuals experiencing wasting diseases (e.g. insulin-dependent diabetes), severe dietary restriction (e.g. anorexics), or who are high-performance athletes (e.g. marathon runners or ballet dancers) may have severely impaired reproductive systems (De Souza \& Metzger, 1991; Stewart, 1992; Griffen et al. 1994). The effect of nutritional status on reproduction is postulated to reflect the action of unknown metabolic signal(s) that are recognized by the brain and serve as indices of metabolic state (Kennedy \& Mitra, 1963). Leptin has been postulated to be either the, or one such, signal. Thus, if metabolic reserves are low or the system is stressed, reproduction will be inhibited (Barash et al. 1996; Chehab et al. 1996).

\section{Restoration of fertility in $o b / o b$ mice}

The sterility of male and female homozygous $o b / o b$ mice is a recognized feature of the $o b$ mutation (Ingalis $e t a l .1950$ ). The $o b / o b$ males can occasionally reproduce if maintained on a restricted diet, but $o b / o b$ females are always sterile (Lane \& Dickie, 1954). Reproductive hormones are reduced in $o b / o b$ females, suggesting a functional defect in the hypothalamic-pituitary axis (Batt, 1972; Batt et al. 1982).

The repeated administration of recombinant human leptin into female $o b / o b$ mice corrects their sterility; thus ovulation, pregnancy, parturition and lactation are each restored (Chehab et al. 1996). In initial studies, it was determined that leptin withdrawal at day 14 of pregnancy did not prevent continued gestation and parturition. However, subsequent generations of the female $o b / o b$ pups were unable to reproduce following leptin withdrawal, demonstrating that correction of their sterility requires continuous leptin treatment (Chehab et al. 1996).

The administration of leptin for $14 \mathrm{~d}$ to female $o b / o b$ mice results in increased ovarian weight compared with pair-fed female $o b / o b$ controls. The histology of the leptin-treated ovary showed greater amounts of follicular development consistent with activation of ovarian function. The trophic action of leptin on gonadal function apparently led to an increase in sex steroids, as shown by increased uterine weights. This appeared to be due to the proliferative growth of the uterine glands, epithelium and endometrium, which is a typical response to stimulation by oestrogen. In addition to the responses in females, male $o b / o b$ mice treated with leptin showed an elevation in testicular weight compared with pairfed male $o b / o b$ controls. Testicular histology suggested that leptin stimulated cellular activity in the seminiferous tubules. The increased weight of the seminal vesicles was accompanied by an increase in epithelial height, indicating increased circulating levels of testosterone (Barash et al. 1996).

\section{A signal triggering the onset of puberty?}

The ability of leptin to restore fertility to mice that are genetically deficient in leptin suggests that this hormone may be a signal triggering the onset of reproductive function. Indeed, leptin has been shown to accelerate the onset of puberty in normal female mice (Ahima et al. 1997; Chehab et al. 1997). Normal pre-pubertal mice injected with leptin reproduce earlier, showing earlier maturation of the reproductive tract as determined by: (1) timing of vaginal opening, (2) progress toward the first oestrus cycle and (3) the weights of uteri, ovaries and oviducts. In mice treated with leptin there was a concomitant decrease in luteinizing hormone and $17 \beta$ oestradiol compared with the saline-treated mice. Leptin treatment did not appear to interfere with successful ovulation, pregnancy or delivery of pups (Ahima et al. 1997; Chehab et al. 1997). Importantly, the effect of leptin on puberty can occur in the absence of any effect on body weight (Ahima et al. 1997). This suggests that the actions of leptin to regulate neuroendocrine and reproductive function in normal mice are not secondary to effects on energy balance.

\section{Hypothalamic-pituitary-gonadal axis}

The presence of functionally-active leptin receptors in the hypothalamus (Mercer et al. 1996b; Schwartz et al. 1996) and the fact that leptin increases luteinizing hormone in female $o b / o b$ mice and fasted normal mice suggested that leptin acts at a central level primarily through the hypothalamic- pituitary-gonadal axis (Chehab et al. 1996, 1997; Ahima et al. 1997). There is strong evidence both from functional studies and from co-localization of the leptin receptor with preproneuropeptide $\mathrm{Y}$ gene expression that hypothalamic neuropeptide $\mathrm{Y}$ is an important neuroendocrine target for leptin (Stephens et al. 1995; Mercer et al. 1996a; Schwartz et al. 1996). Interestingly, neuropeptide $Y$ has been widely implicated in the regulation of gonadotropinreleasing hormone secretion (Kalra, 1993). It has also been 
demonstrated that rats treated intracerebroventricularly with leptin antiserum showed a marked impairment in luteinizing hormone pulsatility, compatible with leptin regulating the reproductive axis by influencing gonadotropin-releasing hormone pulsatility (Carro et al. 1997).

Leptin at very low concentrations has been shown to stimulate luteinizing hormone-releasing hormone release from hypothalamic explants and follicle-stimulating hormone and luteinizing hormone release from anterior pituitaries of adult male rats. This may indicate that leptin plays an important role in controlling gonadotropin secretion by stimulating both hypothalamic and/or pituitary actions (Yu et al. 1997).

In addition, leptin receptors have been reported in the ovary and testis, so leptin may act as a metabolic signal to the reproductive system via a direct action on the gonads (Cioffi et al. 1996). Indeed, leptin has been shown to inhibit insulininduced progesterone and oestradiol production by granulosa cells (Spicer \& Francisco, 1997; Zachow \& Magoffin, 1997). Overall, it seems likely that the action of leptin on the reproductive system arises from a combined influence on the brain and the gonads.

\section{Leptin and its role in pregnancy}

The role of leptin in the restoration of fertility in $o b / o b$ mice and also in the onset of puberty in lean female mice, coupled with its effects on appetite and thermogenesis, suggested that the hormone may play an important role during pregnancy. Indeed, circulating leptin levels appear to rise towards the end of pregnancy in human subjects and in rodents, with a fall in titre to below pre-pregnancy levels at around birth. This effect is particularly pronounced in the mouse, which has been reported to show a 25 -fold rise (Tomimatsu et al . 1997) in leptin on day 17 in the maternal circulation compared with a $2 \cdot 7$-fold and $1 \cdot 8$-fold maximum rise in human subjects (Hardie et al. 1997) and rats (Chien et al. 1997) respectively, relative to the prepregnancy levels.

There appear at present to be three possible explanations for the increase in leptin levels in pregnancy: (1) increased production by maternal fat, (2) expression by the placenta and (3) increased levels of binding protein(s) in the maternal circulation.

\section{Increased production by maternal fat}

In rodents, leptin mRNA levels have been shown to increase during pregnancy in the parametrial adipose tissue, as determined by Northern blotting, compared with the non-pregnant rodent (Tomimatsu et al. 1997). Another report, however, suggests there is no change in expression from this fat depot (Gavrilova et al. 1997). This contradiction remains to be resolved and does not rule out differential expression by other fat depots in the pregnant rodent. During pregnancy a number of hormones increase in concentration, such as cortisol, insulin and oestradiol, and it is interesting to note that these have been shown to stimulate leptin expression in adipocytes from in vivo studies on laboratory animals and/or from cell-culture studies (Shimizu et al. 1997; Trayhurn et al. 1998).

\section{Expression by the placenta}

A recent finding shows that leptin, which was previously thought to be exclusively produced by adipocytes, is also produced at a significant level in the placenta (Green et al. 1995; Hoggard et al. 1997a; Masuzaki et al. 1997). Expression of the leptin gene in the human placenta can be detected by Northern blotting, but this technique is not sensitive enough to detect leptin mRNA in the rodent placenta. However, we have shown leptin gene expression can be detected by reverse transcription-polymerase chain reaction and by in situ hybridization in the murine placenta (Figs. 1 and 2; Hoggard et al. 1997a). Interestingly, high levels of immunoreactive leptin protein can be detected in the murine placenta at levels comparable with those in the human placenta (Fig. 3; Hoggard et al. 1997a; Tomimatsu et al. 1997). Leptin appears to be expressed by the placental trophoblasts in both the rodent (Fig. 4) and human placenta (Masuzaki et al. 1997).

The leptin-like immunoreactivity detected in the human placenta is considered to be identical to human leptin of adipose origin on the basis of size, charge and

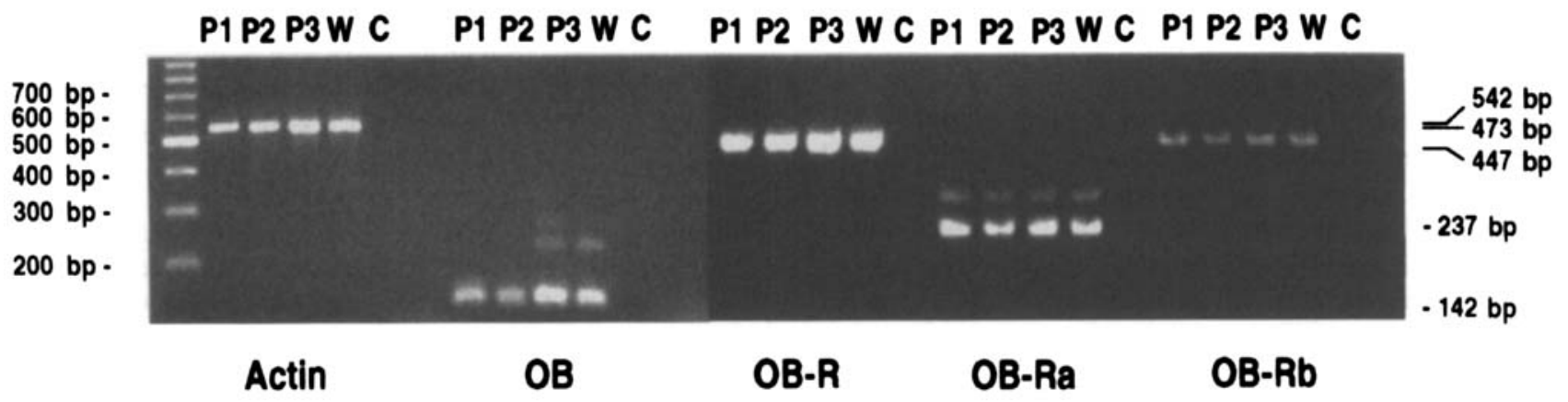

Fig. 1. Reverse transcription-polymerase chain reaction expression analysis of leptin and alternatively-spliced leptin receptors in mouse placentas (P1-P3) and mouse adipose tissue (W). The expression of leptin (OB) was compared with the common extracellular domain of the leptin receptor (OB-R), the short splice variant (OB-Ra) and the signalling form of the leptin receptors (OB-Rb). $\beta$-Actin amplification was used as a control. The tissues were all extracted and reverse transcribed at the same time. No bands were observed with the mock complementary DNA (data not shown) or in the absence of complimentary DNA (C). Molecular markers ( 100 base pair (bp) ladder) and size of reverse transcription-polymerase chain reaction products are shown. 
immunoreactivity (Senaris et al. 1997). The same promoter is used for both human adipose and placental transcription of the leptin gene. However, an upstream enhancer has been identified which functions in the JEG-3 and JAR choriocarcinoma cell lines but not in adipocytes or HeLa cells. Binding analyses demonstrated three protein-binding sites in this enhancer region, designated placental leptin-enhancer elements $1-3$. The protein binding to the placental leptinenhancer element 3 motif appears to be a novel placentaspecific transcription factor (Bi et al. 1997). This implies that human placental leptin is differentially regulated from leptin of adipose origin.

\section{Increased levels of binding protein(s) in the maternal circulation}

In addition to leptin expression in the placenta, we have also shown that the murine placenta expresses high levels of leptin receptor mRNA (Figs. 1 and 2) and protein (Fig. 3). We have identified a number of different receptor splice variants in the murine placenta (Fig. 1). These include OB-Rb, the signalling form of the leptin receptor, and OB-Ra, the proposed transport form of the receptor (Hoggard et al. 1997a). This suggests that the placenta may be a target organ for leptin action. In addition, OB-Re, the soluble form of the

(A)

Leptin

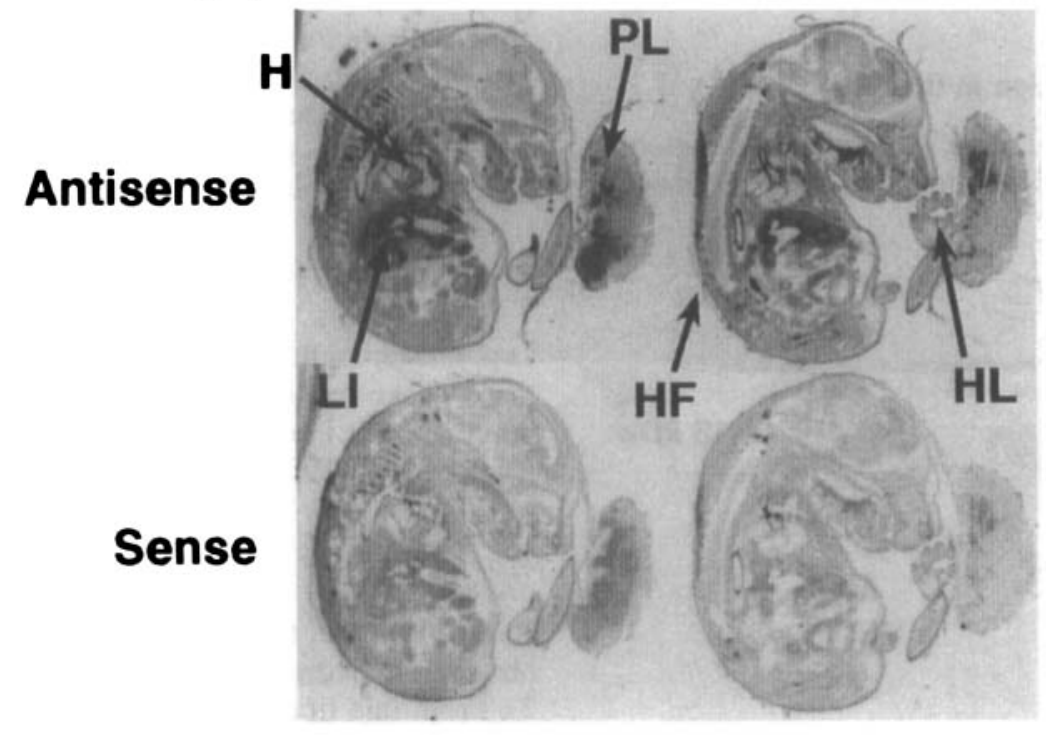

(B)

\section{Antisense}

Sense

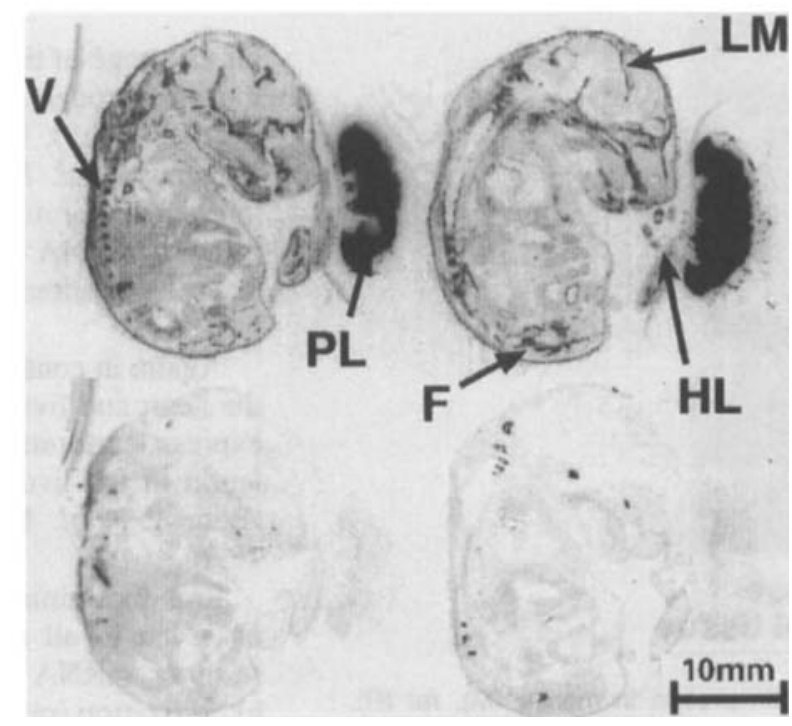

Fig. 2. In situ hybridization to sections of murine fetus and placenta hybridized with a ${ }^{35}$ S-labelled antisense (upper panel) and sense (lower panel) riboprobes to $(A)$ leptin and $(B)$ the common extracellular domain of the leptin receptor (OB-R) mRNA. PL, placenta; LM, leptomeninges; V, vertebrae; F, femur; HL, hindlimb; LI, liver; $H$, heart; HF, hair follicle. 
leptin receptor has been identified (Gavrilova et al. 1997). The soluble form appears to be secreted into the maternal serum where it is suggested that it binds circulating leptin. This may protect the leptin from degradation and/or excretion while preventing it from binding to the signalling form of the leptin receptor, thereby giving rise to leptin resistance (Gavrilova et al. 1997). This proposal has the advantage of explaining the contradiction of a peak in leptin, an appetite suppressant, at a time of increased nutritional requirement. However, the increase in bound circulating leptin during late pregnancy, like the large increase in murine maternal leptin, appears to be restricted to mice and does not occur in human subjects or rats (Gavrilova et al. 1997).

The role of placental leptin and its receptor clearly requires further investigation. The leptin system may play a role in the control of pregnancy, parturition, or in the development of the fetus.

\section{Leptin expression in the fetus}

We have also identified leptin gene expression and mature leptin protein in a number of tissues in the $16 \cdot 5$-d-old murine

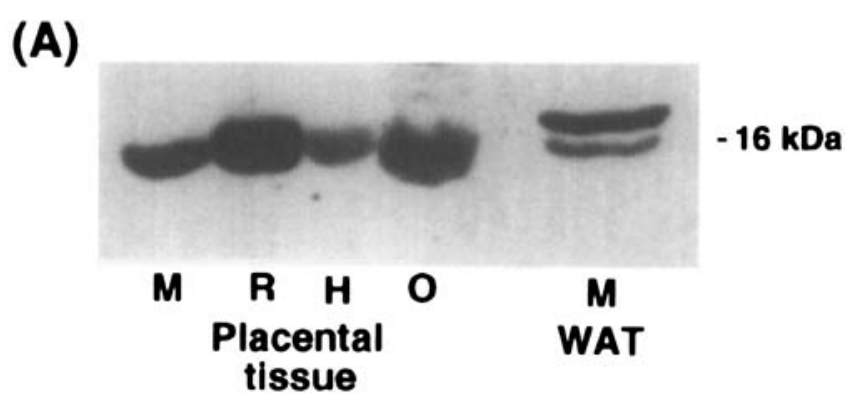

(B)

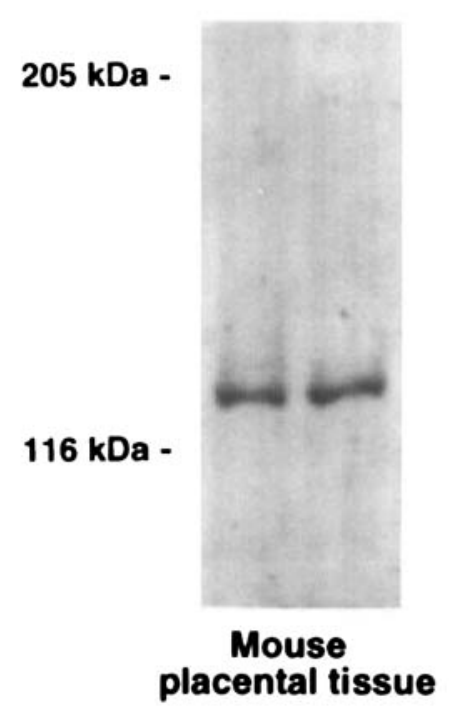

Fig. 3. (A) Western biot of leptin protein in mouse (M), rat (R), human $(\mathrm{H})$ and ovine $(\mathrm{O})$ placentae compared with mouse white adipose tissue (WAT). A major band was observed at $16 \mathrm{kDa}$. (B) Western blot of leptin receptor protein in two mouse placentas. Markers are as shown. $10 \mu \mathrm{g}$ of protein was loaded onto each lane. fetus, by in situ hybridization (Fig. 2) and immunohistochemistry (Fig. 4). The major areas of leptin receptor expression are discussed elsewhere in this symposium.

\section{Fetal cartilage and bone}

High levels of leptin gene expression were observed in the fetal cartilage and bone; in particular the vertebrae, ribs and digits of the hindlimb (Fig. 2). Similarly, using a probe to the leptin receptor for in situ hybridization, high levels of expression were observed in the same cartilage and bone structures that expressed leptin mRNA (Fig. 2), but in a different cell population (data not shown). This suggests that leptin may function in an autocrine or paracrine manner in the fetus (Fig. 2).

The expression of high levels of leptin and its receptor (both mRNA and protein) in the fetal bone and cartilage implies a role for leptin in fetal bone and/or cartilage development, which may be linked to its influence on haematopoiesis in the adult (Bennett et al. 1996; Cioffi et al. 1996; Gainsford et al. 1996) and/or represent a new function for leptin in bone development.

\section{Brain}

Leptin receptor mRNA and leptin receptor protein were identified in the leptomeninges and choroid plexus of the fetal brain (Fig. 2), confirming earlier studies in the adult rodent (Mercer et al. 1996b; Schwartz et al. 1996).

\section{Hair follicles}

Hybridization of the leptin probe and the receptor probe was observed over the hair follicles, including the verbrisae (Fig. 2). From this finding it is tempting to speculate that leptin plays a role in thermoregulation (Trayhurn et al. 1998).

\section{Other fetal tissues}

Of the range of tissues that express leptin receptor mRNA in the adult rodent, with the exception of the brain tissues (Tartaglia et al. 1995; Ghilardi et al. 1996; Lee et al. 1996; Hoggard et al. 1997b), only the lung and kidney express leptin receptor mRNA in the murine fetus (Fig. 2). No leptin receptor mRNA or protein expression was identified in the heart, liver, adrenal, or pancreatic primordium of the murine fetus.

Again, in contrast to previous published data in the adult, the heart and liver of the 16.5-d-old murine fetus appear to express leptin mRNA and protein (Fig. 2). The presence of leptin in the liver may relate to its role in haematopoesis (Bennett et al. 1996; Cioffi et al. 1996; Gainsford et al. 1996).

Immunostaining for leptin and the leptin receptor was observed in all tissues examined where leptin and leptin receptor mRNA had previously been detected by in situ hybridization (placenta only shown; Fig. 4).

The high levels of expression of both leptin and leptin receptors in the fetus suggest that this cytokine plays a key role in fetal development. One possible role is that of a fetal 
(A)

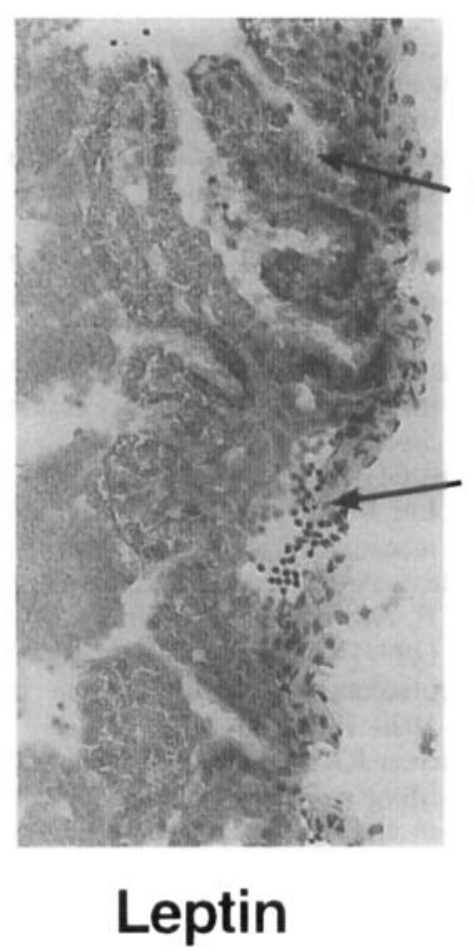

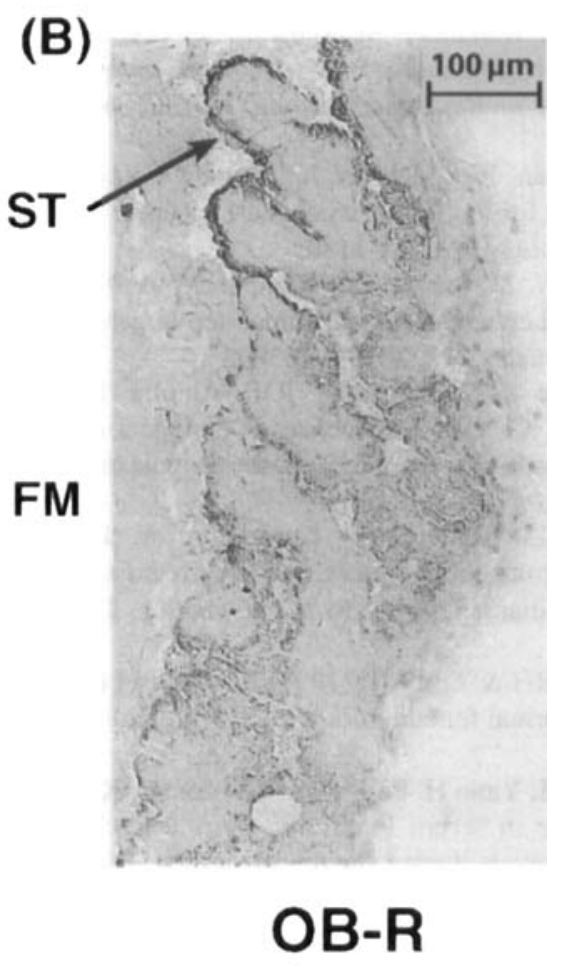

Fig. 4. Murine tissue sections of placenta were incubated with (A) leptin antiserum and (B) leptin receptor (OB-R) antiserum. The immunoreaction is visualized by 3,3'-diaminobenzidine, positive cells giving a brown colour at the site of reaction. The specificity of the immunoreaction of leptin and OB-R was confirmed by omission of the primary antibody (not shown). In case of leptin specificity, this was further confirmed by preabsorption of the leptin antiserum with synthetic leptin (not shown). Sections were counter-stained with toluidine blue. ST, syncytial trophoblast; FM, fetal mesenchyme.

growth factor, or as a signal to the fetus of maternal energy status. Alternatively, fetal leptin could provide a signal to the mother of fetal growth and development. However, it should be noted that leptin-deficient $o b / o b$ murine fetuses appear to develop normally. In addition, two very obese children with a frameshift mutation in the leptin gene (who essentially display the same phenotype as $o b / o b$ mice) also appear to be developing normally (in respects other than the obesity) and were born with normal birth weights. They do, however, have abnormalities of growth in the long bones of their legs and this may relate to the leptin expression detected in the fetal bone and cartilage (Montague et al. 1997). In summary, leptin expression in the fetus appears to be multifunctional, with both paracrine and endocrine effects.

\section{Conclusion}

Leptin has an extensive role to play in reproduction. It has been shown to restore the fertility of infertile leptin-deficient $o b / o b$ mice, and it is also involved in the onset of puberty in normal mice. Recently, attention has focused on the increase in circulating maternal leptin towards the end of pregnancy and the placental expression of leptin. We have shown that although leptin gene expression is not detectable by Northern blot analysis in the murine placenta, it is still expressed at levels high enough to be detected by in situ hybridization. The question still remains as to the function of placental leptin, particularly when leptin in the human placenta appears to be differentially regulated. Is it secreted to the maternal or fetal circulation? Is it involved in maternal appetite regulation? Leptin and its receptor are also present in the murine fetus, where leptin appears to be multifunctional, with both paracrine and endocrine effects which require further investigation.

\section{Acknowledgements}

This work is supported by the Scottish Office Agriculture, Environment and Fisheries Department. We are grateful to $\mathrm{Mr}$ R. A. Duthie for graphics expertise.

\section{References}

Ahima RS, Dushay J, Flier SN, Prabakaran D \& Flier JS (1997) Leptin accelerates the onset of puberty in normal female mice. Journal of Clinical Investigation 99, 391-395.

Barash IA, Cheung CC, Weigle DS, Ren HP, Kabigting EB, Kuijper JL, Clifton DK \& Steiner RA (1996) Leptin is a metabolic signal to the reproductive-system. Endocrinology 137, 3144-3147.

Batt RAL (1972) The response of the reproductive system in the female mutant mouse, obese (genotype $o b / o b$ ) to gonadotrophinreleasing hormones. Journal of Reproduction and Fertility 31, $496-497$. 
Batt R, Everard D, Gilles G, Wilkinson M, Wilson C \& Yeo T (1982) Investigation into hypogonadism of the obese mouse (genotype $o b / o b$ ). Journal of Reproduction and Fertility 64, 363-371.

Bennett BD, Solar GP, Yuan JQ, Mathias J, Thomas GR \& Matthews W (1996) A role for leptin and its cognate receptor in hematopoiesis. Current Biology 6, 1170-1180.

Bi S, Gavrilova O, Gong DW, Mason MM \& Reitman M (1997) Identification of a placental enhancer for the human leptin gene. Journal of Biological Chemistry 272, 30583-30588.

Carro E, Pinilla L, Seoane LM, Considine RV, Aguilar E, Casanueva FF \& Dieguez C (1997) Influence of endogenous leptin tone on the estrous cycle and luteinizing hormone pulsatility in female rats. Neuroendocrinology 66, 375-377.

Chehab FF, Lim ME \& Lu RH (1996) Correction of the sterility defect in homozygous obese female mice by treatment with the human recombinant leptin. Nature Genetics 12, 318-320.

Chehab FF, Mounzih K, Lu RH \& Lim ME (1997) Early onset of reproductive function in normal female mice treated with leptin. Science 275, 88-90.

Chien EK, Hara M, Rouard M, Yano H, Phillippe M, Polonsky KS \& Bell GI (1997) Increase in serum leptin and uterine leptin receptor messenger RNA levels during pregnancy in rats. Biochemical and Biophysical Research Communications 237, 476-480.

Cioffi JA, Shafer AW, Zupancic TJ, Smith-Gbur J, Mikhail A, Platika D \& Snodgrass HR (1996) Novel B219/Ob receptor isoforms - possible role of leptin in hematopoiesis and reproduction. Nature Medicine 2, 585-589.

De Souza M \& Metzger D (1991) Reproductive dysfunction in amenorrheic athletes and anorexic patients: a review. Medicine and Science in Sports and Exercise 23, 995-1007.

Gainsford T, Willson TA, Metcalf D, Handman E, McFarlane C, Ng A, Nicola NA, Alexander WS \& Hilton DJ (1996) Leptin can induce proliferation, differentiation, and functional activation of hematopoietic-cells. Proceedings of the National Academy of Sciences USA 93, 14564-14568.

Gavrilova O, Barr V, Marcus-Samuels B \& Reitman M (1997) Hyperleptinemia of pregnancy associated with the appearance of a circulating form of the leptin receptor. Journal of Biological Chemistry 272, 30546-30551.

Ghilardi N, Ziegler S, Wiestner A, Stoffel R, Heim MH \& Skoda RC (1996) Defective STAT signaling by the leptin receptors in diabetic mice. Proceedings of the National Academy of Sciences USA 93, 6231-6235.

Green ED, Maffei M, Braden VV, Proenca R, Desilva U, Zhang YY, Chua SC, Leibel RL, Weissenbach J \& Friedman JM (1995) The human obese $(\mathrm{Ob})$ gene - RNA expression pattern and mapping on the physical, cytogenetic, and genetic maps of chromosome-7. Genome Research 5, 5-12.

Griffen M, South S, Yankov V, Booth RJ, Asplin C, Veldhuis J \& Evans W (1994) Insulin dependent diabetes mellitus and menstrual dysfunction. Annals of Medicine 26, 331-340.

Hardie L, Trayhurn P, Abramovich D \& Fowler P (1997) Circulating leptin in women: a longitudinal study in the menstrual cycle and during pregnancy. Clinical Endocrinology 47, 101-106.

Hoggard N, Hunter L, Duncan JS, Williams LM, Trayhurn P \& Mercer JG (1997a) Leptin and leptin receptor mRNA and protein expression in the murine fetus and placenta. Proceedings of the National Academy of Sciences USA 94, 11073-11078.

Hoggard N, Mercer JG, Rayner DV, Moar K, Trayhurn P \& Williams LM (1997b) Localization of leptin receptor mRNA splice variants in murine peripheral tissues by RT-PCR and in situ hybridization. Biochemical and Biophysical Research Communications 232, 383-387.

Ingalis AM, Dickie MM \& Snell GD (1950) Obese, a new mutation in the house mouse. Journal of Heredity $45,317-318$.

Kalra S (1993) Mandatory neuropeptide-steroid signaling for the preovulatory luteinizing hormone-releasing hormone discharge. Endocrine Reviews 14, 507-538.

Kennedy GC \& Mitra J (1963) Hypothalamic control of energy balance and the reproductive cycle in the rat. Journal of Physiology 166, 395-407.

Lane PW \& Dickie MM (1954) Relative sterility in obese males corrected by dietary restriction. Journal of Heredity $\mathbf{4 5}$, $56-58$.

Lee GH, Proenca R, Montez JM, Carroll KM, Darvishzadeh JG, Lee JI \& Friedman JM (1996) Abnormal splicing of the leptin receptor in diabetic mice. Nature 379, 632-635.

Masuzaki H, Ogawa Y, Sagawa N, Hosoda K, Matsumoto T, Mise H, Nishimura H, Yoshimasa Y, Tanaka I, Mori T \& Nakao K (1997) Nonadipose tissue production of leptin: Leptin as a novel placenta-derived hormone in humans. Nature Medicine 3, 1029-1033.

Mercer JG, Hoggard N, Williams LM, Lawrence CB, Hannah LT, Morgan PJ \& Trayhurn P (1996a) Coexpression of leptin receptor and preproneuropeptide-Y messenger-RNA in arcuate nucleus of mouse hypothalamus. Journal of Neuroendocrinology 8, 733-735.

Mercer JG, Hoggard N, Williams LM, Lawrence CB, Hannah LT \& Trayhurn P (1996b) Localization of leptin receptor messengerRNA and the long form splice variant (Ob-Rb) in mouse hypothalamus and adjacent brain-regions by in-situ hybridization. FEBS Letters 387, 113-116.

Montague CT, Farooqi IS, Whitehead JP, Soos MA, Rau H, Wareham NJ, Sewter CP, Digby JE, Mohammed SN, Hurst JA, Cheetham CH, Earley AR, Barnett AH, Prins JB \& O'Rahilly S (1997) Congenital leptin deficiency is associated with severe early-onset obesity in humans. Nature 387, 903-908.

Schwartz MW, Seeley RJ, Campfield LA, Burn P \& Baskin DG (1996) Identification of targets of leptin action in rat hypothalamus. Journal of Clinical Investigation 98, 1101-1106.

Senaris R, Garcia-Caballero T, Casabiell X, Gallego R, Castro R, Considine RV, Dieguez C \& Casanueva FF (1997) Synthesis of leptin in human placenta. Endocrinology 138, 4501-4504.

Shimizu H, Shimomura Y, Nakanishi Y, Futawatari T, Ohtani K, Sato N \& Mori M (1997) Estrogen increases in vivo leptin production in rats and human subjects. Journal of Endocrinology 154, 285-292.

Spicer LJ \& Francisco CC (1997) The adipose obese gene product, leptin: evidence of a direct inhibitory role in ovarian function. Endocrinology 138, 3374-3379.

Stephens TW, Basinski M, Bristow PK, Buevalleskey JM, Burgett SG, Craft L, Hale J, Hoffman J, Hsiung HM, Kriauciunas A, Mackellar W, Rosteck PR, Schoner B, Smith D, Tinsley FC, Zhang XY \& Heiman M (1995) The role of neuropeptide-Y in the antiobesity action of the obese gene-product. Nature 377 , 539-532.

Stewart D (1992) Reproductive functions in eating disorders. Annals of Medicine 24, 287-291.

Tartaglia LA, Dembski M, Weng X, Deng NH, Culpepper J, Devos R, Richards GJ, Campfield LA, Clark FT, Deeds J, Muir C, Sanker S, Moriarty A, Moore KJ, Smutko JS, Mays GG, Woolf EA, Monroe CA \& Tepper RI (1995) Identification and expression cloning of a leptin receptor, Ob-R. Cell 83, 1263-1271.

Tomimatsu T, Yamaguchi M, Murakami T, Ogura K, Sakata M, Mitsuda N, Kanzaki T, Kurachi H, Irahara M, Miyake A, Shima K, Aono T \& Murata Y (1997) Increase of mouse leptin 
production by adipose tissue after midpregnancy: gestational profile of serum leptin concentration. Biochemical and Biophysical Research Communications 240, 213-215.

Trayhurn P, Hardie LJ, Hoggard N \& Rayner DV (1998) Regulation of leptin production. In Leptin - the Voice of the Adipose Tissue, pp. 69-77 [WF Blum, W Kiess and W Rasher, editors]. Heidelberg, Germany: J.A. Barth Verlag.

Van Der Spuy Z (1985) Nutrition and reproduction. Clinical Obstetrics and Gynaecology 12, 579-604.
Yu WH, Kimura M, Walczewska A, Karanth S \& McCann, SM (1997) Role of leptin in hypothalamic-pituitary function. Proceedings of the National Academy of Sciences USA 94, 1023-1028.

Zachow RJ \& Magoffin DA (1997) Direct intraovarian effects of leptin: impairment of the synergistic action of insulin-like growth factor-I on follicle-stimulating hormone-dependent estradiol-17 beta production by rat ovarian granulosa cells. Endocrinology 138, 847-850. 